\title{
Ras-Related Protein Rab-44
}

National Cancer Institute

\section{Source}

National Cancer Institute. Ras-Related Protein Rab-44. NCI Thesaurus. Code C162428.

Ras-related protein Rab-44 (1021 aa, $111 \mathrm{kDa}$ ) is encoded by the human RAB44 gene.

This protein is involved in signaling and neutrophil degranulation. 